\title{
The effectiveness of cognitive skills recovery program on avoiding scribbling in elementary students
}

\author{
Sakineh Soltani Kouhbanani ${ }^{1 *}$ iD , Somayeh Zarenezhad ${ }^{2}$, Mohammad Hossein Soltani \\ Kouhbanani $^{3}$, Razieh Khosrorad ${ }^{4}$
}

\begin{abstract}
1. Assistant Professor, Department of Counseling and Educational Psychology, Ferdowsi University of Mashhad, Mashhad, Iran

2. MA of Educational Psychology, Department of Counseling and Educational Psychology, Ferdowsi University of Mashhad, Mashhad, Iran

3. Student of Medicine, Faculty of Medicine, Mashhad University of Medical Sciences, Mashhad, Iran

4. Assistant Professor, Department of Health Education, Education Development Center, Sabzevar

University of Medical Sciences, Sabzevar, Iran
\end{abstract}

Recieved: 5 Nov. 2018

Revised: 30 Jan. 2019

Accepted: 4 Mar. 2019

Keywords

Reconstructive cognitive skills

Scribbling

Elementary students

Corresponding author

Sakineh Soltani Kouhbanani, Assistant Professor, Department of Counseling and Educational Psychology, Ferdowsi University of Mashhad, Mashhad, Iran

Email: S.soltani@um.ac.ir

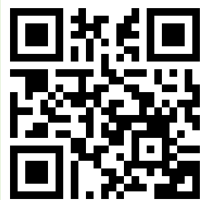

doi.org/10.30699/icss.22.1.116

\section{Abstract}

Introduction: The purpose of this study was to investigate the effect of the cognitive skill rehabilitation program on improper badge marking of primary school students.

Methods: In this research, the participants included elementary students in Khorasan Razavi province in the academic year of 2017-2018 and a descriptive research method of a semi-experimental type. Using purposeful sampling, firstly, elementary students at the third grade in the School of Mashhad were studied by a researched logbook in terms of handwriting problems. After identifying students with poorly-labeled badges, ten of them were randomly selected to receive instruction and trained for 12 sessions ( 45 minutes) each session lasted one hour. The data gathering tool was a review of the research problems of the research line, which was used as a record sheet for behaviors that have a lasting effect. The student's line of problems is examined in this notebook and the teacher identified and introduced students with line problems through observing and reviewing the student's line and responding to the checklist.

Results: The results revealed that the program's reconstruction of perceptual skills had an impact on reducing primary school students' poblems.

Conclusion: In addition to the physical and educational dimensions affecting the reduction of linguistic problems, it should be noted that other factors such as personality traits of the student education, should be considered. According to the observations made during the training and evaluation, has a significant role, so education should not only focus on one dimension and ignore other dimensions.

Citation: Soltani Kouhbanani S, Zarenezhad S, Soltani Kouhbanani MH, Khosrorad R. The effectiveness of cognitive skills recovery program on avoiding scribbling in elementary students. Advances in Cognitive Sciences. 2020;22(1):116-127. 


\title{
اثربخشى برنامه بازسازى مهارتهاى ادراكى بر بهبود بدخط نويسى

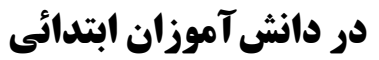

\author{
سكينه سلطانى كوهبنانى'"(D) ، سميه زارع نزاد'، محمد حسين سلطانى كوهبنانى"، راضيه خسروراد"
}

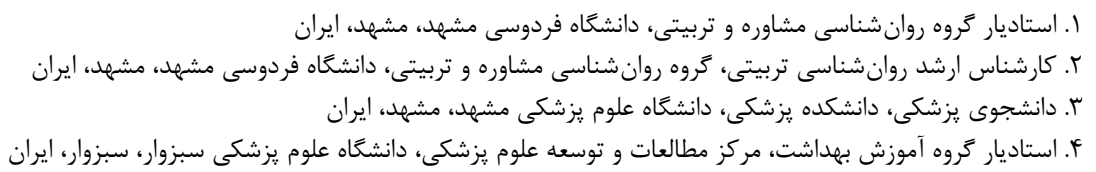

\section{ars}

مقلدمه: مشكلات بدخط نويسى يكى از مهممترين مشكلات حوزه اختلال هاى يادكيرى محسوب مىشود. يروهش حاضر با هدف بررسى تأثير برنامه بازسازى مهارتهاى ادراكى بر بهبود بدخط نويسى دانش آموزان ابتدائى بود.

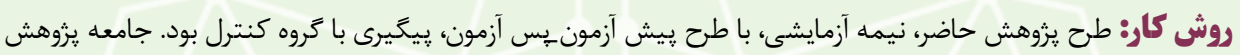
حاضر شامل كليه دانشآموزان مقطع ابتدائى شهر مشهد در سال تحصيلى \\-9 بود. روش نمونه گيرى به صورت هدفمند بود، به اين صورت كه ابتدا دانش آموزان ابتدائى در پايه سوم ابتدايى شهر مشهد به وسيله سياهه محقق ساخته

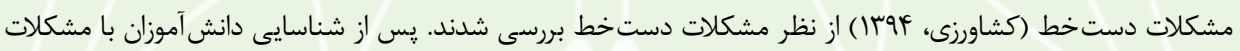
بدخط نويسى •r نفر با داشتن معيارهاى ورود به اين مطالعه انتخاب و سيس به روش گمارش تصادفى در دو گروه كنترل

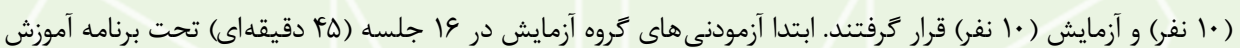
بازسازى مهارتهاى ادراكى قرار گرفتند، در يايان هر دو گروه مجددأ مورد ارزيابى قرار گرفتند. يافته ها: نتايج به دست آمده نشان داد برنامه بازسازى مهارتهاى ادراكى بر كاهش مشكلات خط دانش آموزان ابتدائى تأثير دارد (P) نتيجه گَيرى: بر اساس يافته هاى يزوهش حاضر، علاوه بر ابعاد جسمى و آموزشى مؤثر بر كاهش مشكلات خط، بايد به عوامل ديكرى از جمله ويثگى هاى شخصيتى دانشآموز نيز توجه نمود. طبق مشاهداتى كه در هنگام آموزش و ارزيابى انجام شد، بُعد ادراكى فرد در آموزش نقش بسزايى دارد، بنابراين مىتوان برنامه بازسازى مهارتهاى ادراكى را براى بهببود بدخط نويسى در دانش آموزان ابتدائى به كار برد.
دريافت:

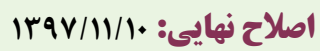

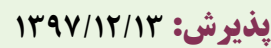

وازههاى كليلدى

بازسازى مهارتهاى ادراكى

بدخط نويسى

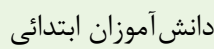

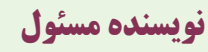

سكينه سلطانى كوهبنانى، عضو هيات

علمى گروه روانشناسى مشاوره و تربيتى،

دانشخاه فردوسى مشهر، مشهرد، ايران

ايميل:S.soltani@um.ac.ir

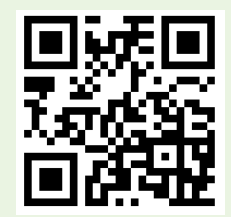

doi doi.org/10.30699/icss.22.1.116

مقلدمه

ولى قادر به گوش دادن، صحبت كردن، خواندن، نوشتن، و يا توسعه مهارتهاى رياضى مطابق با توانايىهاىشان نيستند ( (1). كودكان با اختلال يادكيرى اغلب تا قبل از سن مدرسه شناسايى نمىشوند و مشكلات آنها در دوران مدرسه و در مواجه با تكاليف درسى خاص مشخص مىشود و ممكن است در جند درس يا فقط در يك درس
اصطلاح اختلال يادَيرى را اولين بار Kirk در سال سو91 براى توصيف گروهى از كودكان كه در تحول زبان، كفتار، خواندن و مهارتهاى ارتباطى دجار نارسايى بودند پيشنهاد كرد. مفهوم اختلال يادگيرى با مفهوم عدم ييشرفت غيرمنتظره معادل است. اين مفهوم به ويزه براى دانشآموزانى كاربرد دارد كه اگرجه فرصت كافى براى يادگيرى دارند 
مشكلات اجتماعى و هيجانى آسيب :پيرتر هستند (1). نوشتن يك فرايند يِيجيده از بيان است كه هماهنكى دست و جشهم، زبانشناسى و توانايىهاى ادراكى با هم در آن دخيل هستند (T (I). مشكلات بدخط نويسى يكى از مهمترين مشكلات حوزه اختلال هاى ياد گيرى محسوب مىشود. خط، مهارت ييجيدهاى است كه از تركيب عملكردهاى گوناگون از جمله كنترل حركتى ظريف، توجه، حس حركت (Kinesthesia)، حس عمق (Proprioception)، و مهارت هاى (َ) ادراكى_ديدارى به دست مى آيد (با (). در واقع، خط مهارتى است متكى بر مهارتهاى ادراكى، حركتى، شناختى و زبان شناختى (I ( ). يكى از تعاريف جامع دست خط عبارت است از توانايى نوشتن حروف و اعداد به صورت خوانا و در مدت زمان معين (ها ). پس زمانى كه از خط صحبت مىشود، منظور مهارت مكانيكى نوشتن است از جمله خوانايى و سرعت نوشتن و تمركز ما بر خوانايى خط مى باشد. قبل از يرداختن به موضوع خوانايى دست خط، لازم است تفاوت بين وازههاى نوشتن، دستنويسى لنى و خوشنويسى توضيح داده شود. بين دو وازه نوشتن و دستنويسى تفاوت وجود دارد، به اين معنى كه وقتى صحبت از نوشتن مىشود، منظور مضمون و محتواى نوشته است مثل انشاء و بنابراين بيشتر به مسائل زبانشناختى توجه مىشود. ولى زمانى كه از وازه دستنويسى استفاده مىشود، منظور ويزگى هاى صورى نوشتار شامل خوانايى و سرعت نوشته است و به عوامل محتوايى متن توجهى نمى شود. ابهام ديخرى كه بايد توضيح داده شود تفاوت دستنويسى با خوشنويسى است، در دستنويسى دو مؤلفه بررسى مى شود: خوانايى و سرعت، به

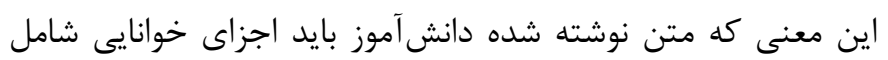
شكل حروف، روى خطنويسى و در يك راستا بودن، فاصله گذارى،

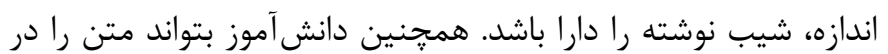
مدت زمان مطلوب به اتمام برساند، اما خوشنويسى هنرى برخاسته از دست است كه در آن زيبايى خط مطرح است و نياز به فرايندهاى عالى تر ذهن دارد (ع). خوانا بودن دستخط را بر اساس اجزاى آن مى سنجند كه شامل روى خطنويسى حروف و كلمات، در يك راستا بودن، فاصله كذارى مناسب، اندازه و شيب نوشته مىباشد (IV). مشكلات دست خط ناشى از عوامل محيطى مانند قلم نامناسب، سطح نامناسب براى نوشتن يا وضعيت بدنى نامناسب در حين نوشتن است و يا ناشى از عوامل درونى است كه به قابليتهاى ذاتى دانش آموزان از قبيل هماهنگیى بينايى_حركتى، برنامهريزى حركتى، كنترل حركات ظريف و توانايى دستكارى مناسب ابزار نوشتن در دست اطلاق مى شود كه ممكن است در بين دانش آموزان دختر و يسر نيز متفاوت باشد (1) (1).
خاص دجار مشكل باشند (Y). تاكنون تعاريف مختلفى درباره اختلالات يادگيرى مطرح شده است. تعريف اختلالات يادگيرى به گروهى ناهمگن از نارسايىها اطلاق مىشود كه به صورت دشوارى جدى در فراگيرى و كاربرد گوش دادن، حرف زدن، خواندن، نوشتن و محاسبه

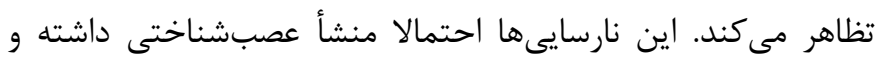
داراى يك روند تحولى است كه از بيش از دبستان شروع و تا بزرگسالى لى

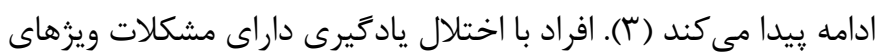
در يادگيرى تحصيلى (خواندن، نوشتن و رياضى) هستند. بر اساس راهنماى تجديدنظر شده تشخيصى و آمارى اختلالهاى روانى (- DSM5)، مطالعات مختلف دامنه شيوع ا تا • ب درصد را براى ناتوانى هاى ياد گيرى در ميان كودكان مدرسه گزارش كردهاند (F) و معمولاً تعداد يسرها سه برابر دخترها است ( (1). اختلالات يادگيرى با شيوع ه تا ها درصد مهمترين علت عملكرد ضعيف تحصيلى و اجتماعى به شمار مىرود. با توجه به اين كه از بين دورههاى مختلف زندگى انسان، دوران كودكى و نوجوانى از مهرمترين و حساسترين مراحل زندگى (تغييرات عميق) هر فرد به شمار مىرود، مشكلات يادگيرى در اين سنين مىتواند زمينهساز ناساز كارىهاى تحصيلى و اجتماعى در آينده شود. در اين دوران، تغييراتى در جنبه هاى مهرم روانى، عقلانى، جسمانى و كائى اجتماعى كودك و نوجوان رخ مى دهد كه هر كدام به نوعى بر او اثر مى گذارد. كودكان و نوجوانان در اين دوران شناخت گستردهترى از خود و همسالان ييدا مى كنند، نقشهاى متفاوتى را بر عهده مى و مهارتهاى تازهاى קيدا مى كنند (ه). در هر جامعه سلامت كودكان و نوجوانان اهميت ويزهاى دارد و توجه به بهداشت روانى آنها كمك مه مى كند تا از نظر روانى و جسمى سالم بوده، نقش اجتماعى خود را بهتر ايفا كنند (9). در اين راستا، شناخت صحيح ابعاد مختلف جسمى روى و روانى اين گروه سنى و كوشش در راه تأمين شرايط مادى و معنوى مناسب براى رشد بدنى، عاطفى و فكرى آنان واضحتر از آن است كه احتياج به تأكيد داشته باشد (9). يزوهشهاى مختلف نشان دادند كه دانشآموزان با اختلال يادگيرى خاص نرخ بالاترى از مشكلات تحصيلى، عاطفى و اجتماعى را نسبت به كودكان عادى دارند (V، A). اختلال يادكيرى واقعيت غير قابل انكارى است كه در تمام جوامع و فرهنَ ها به جشم مى خورد و به عنوان يكى از معضلهاى مهلم و تعيين كننده سرنوشت تحصيلى دانش آموزان به شمار مى آيد (9). دانشآموزان مبتلا به ناتوانى يادگيرى اغلب ديد بسيار منفى نسبت به خود دارند و در نتيجه نكاه آنان به خودشان به عنوان يك فرد ناتوان و بى كفايت تغيير شكل مى يابد (• (). دانشآموزان با اختلالات يادَيرى كه به طور مداوم و مكرر شكست تحصيلى را تجربه مى كنند نسبت به 
ي ״يشبينى كننده خوانايى دست خط در دانشآموزان كلاس دوم است.

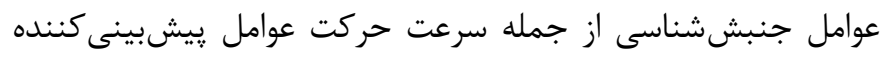

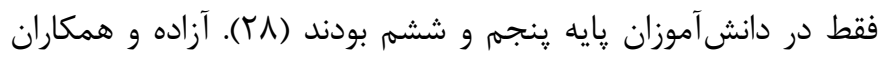

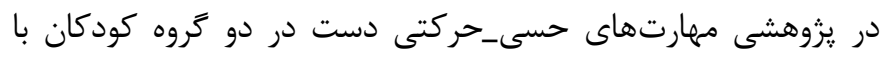

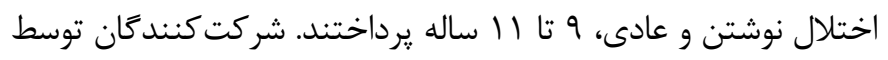
آزمون هاى آستانه حس لمس سبك عادى (فشار عمقى)، مهارت حركتى دست، مهارتنويسى مينوستا، قدرت گرفتن درشت، قدرت كرفتن ظريف مورد ارزيابى قرار كرفتند. دست مورد مطالعه دست غالب (دست راست) بود. نتايج حاكى از آن بود كه مهارتهاى حسى_حركتى دست در كودكان با اختلال بدخط نويسى به صورت معنادارى ضعيفتر از كودكان عادى در إن بهر

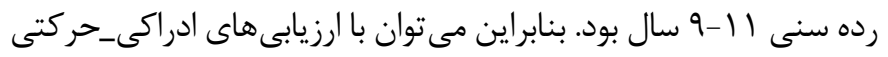

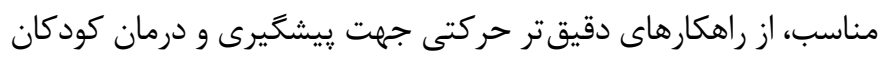

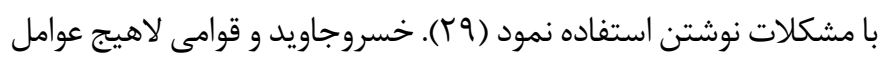

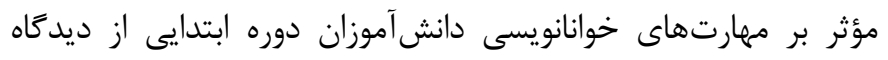
معلمان را مورد بررسى قرار دادند. نتايج حاصل نشان داد كه عوامل

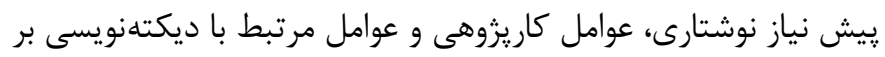
خوانانويسى دانشآموزان مؤثر است و عوامل مربوط به خطاهاى متداول

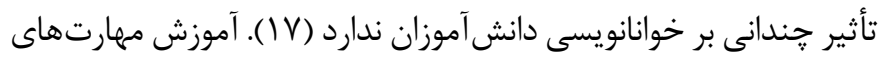

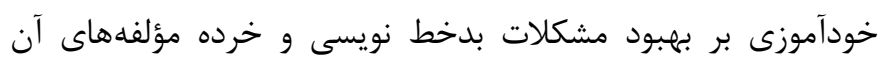
(خطاهاى بدخط نويسى و خطاهاى وضعيت بدن هنغام نوشتن) تأثير دارد

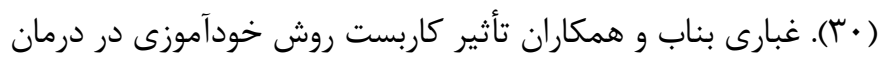

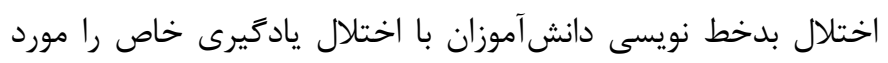

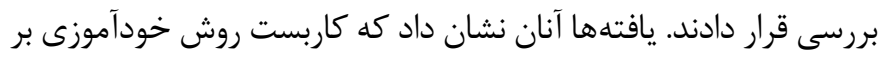
بهببود كيفيت خط دست خط آزمودنى هاى مورد مطالعه تأثير داشته است. همجنين روش خودآموزى بر درمان بدخط نويسى دانش آموزان با اختلال

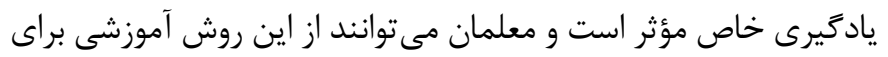
بهبود عملكرد نوشتن در اين دانشآموزان استفاده كنند (آ). در ادامه

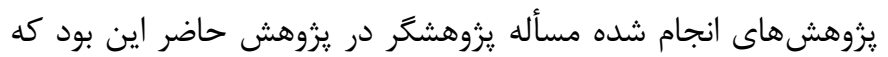

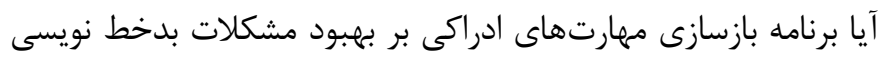
اعضاى نمونه يزوهش تأثير دارد يا خير؟

\section{روش كار}

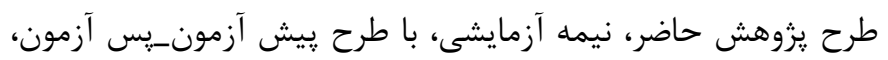

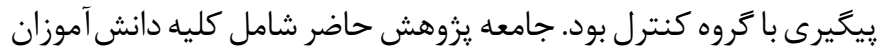

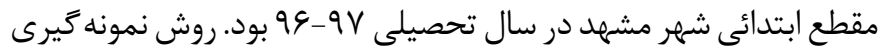

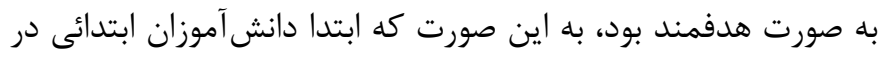
بايه سوم ابتدايى شهر مشهد به وسيله سياهdمحقق ساخته مشكلات
دستخط مهارتى دشوار براى كودكان است (9 ). استفاده از كاغذ و ابزار

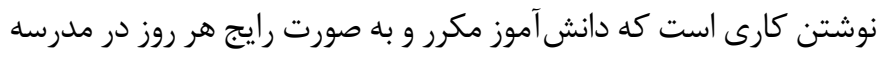
انجام مى دهد (•r). وجود مشكل در اين فرايند يادگيرى اغلب منجر

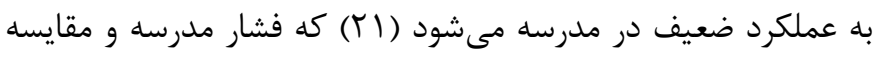

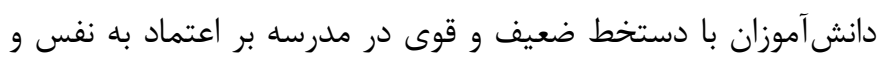

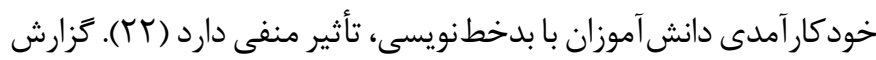
شده است كه عملكرد بدخط نويسى بر تصور از خود، يِيشرفت علمى و

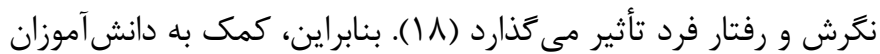
با بدخط نويسى باعث مىشود در مدرسه از حداكثر توانايىشان استفاده

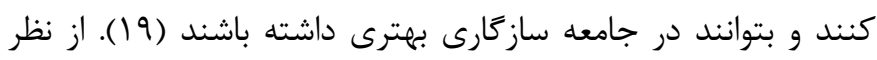

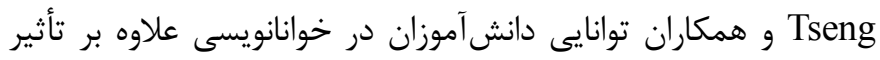

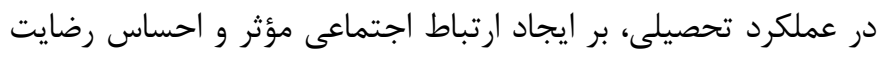

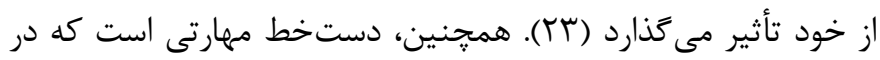

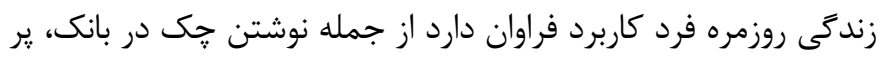

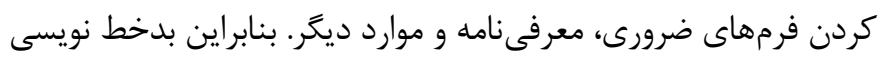

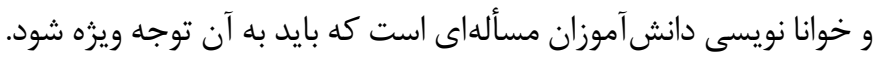
مشكلات خوانانويسى در ·ــ-• درصد كودكان دبستانى، حتى آنهايى كه از لحاظ هوشى طبيعى هستند و مشكلات عصبشناختى واضحى

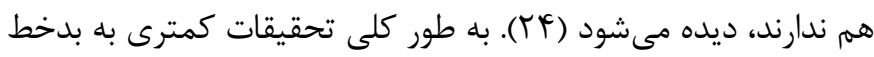

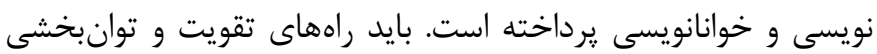

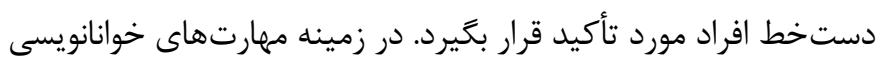

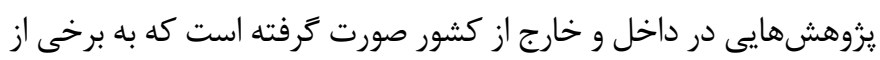

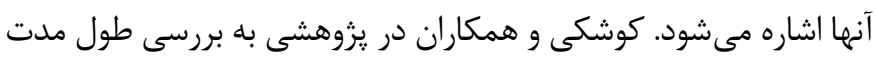
تكليف نوشتن در كودكان باو بدون مشكلات دستخط يرداختند. نتايج نشان داد كيفيت و سرعت نوشتن با توجه به طول مدت نوشتن متفاوت

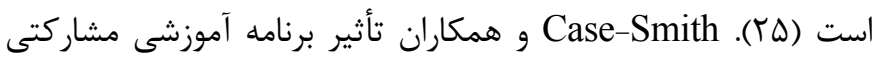

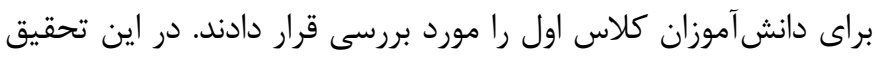

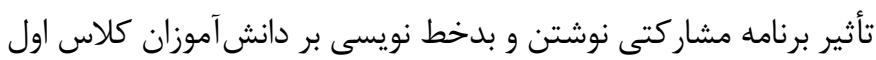

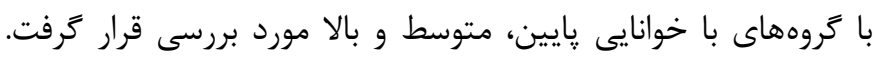

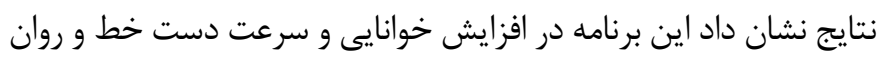
نوشتن سودمند است (צY). يزوهشى با عنوان نحوه كرفتن مداد و تأثير

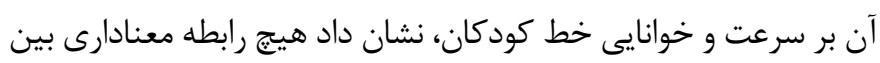

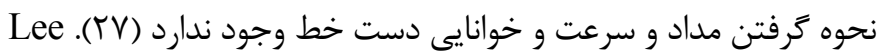
و همكاران ييشبينى كنندههاى دستخط را مطرح كردند و بيان داشتند عوامل ييشبينى كننده بدخط نويسى در كروه هاى سنى مختلف، متفاوت

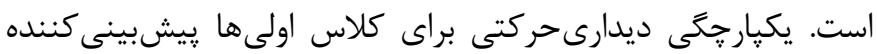

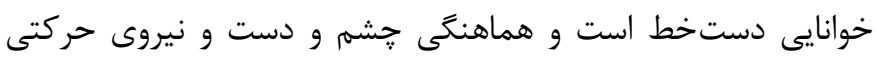


مؤلفه خطاهاى دستخط و خطاهاى وضعيت بدن هنكام نوشتن بود. خرده مؤلفه خطاهاى دست خط شامل IV كويه و خرده مؤلفه خطاهاى

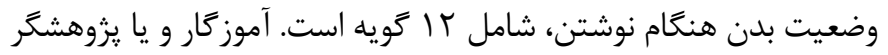

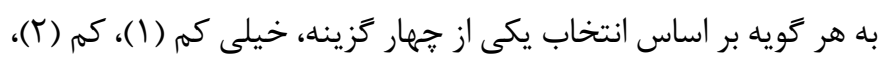

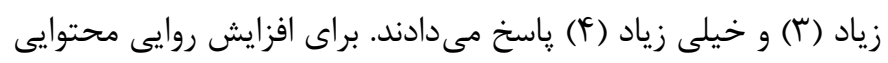

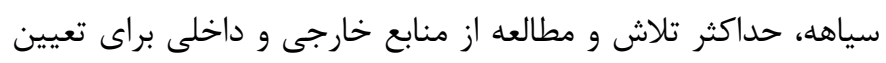
كستره خطاهاى دست خط مربوط به دانش آموزان صورت كرفت. سرانجام

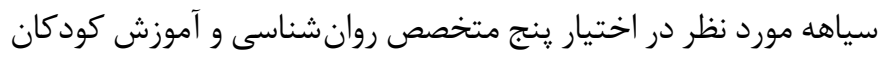
استثنايى و اختلال هاى يادگيرى قرار گرفت كه طى آن روايى محتوايى

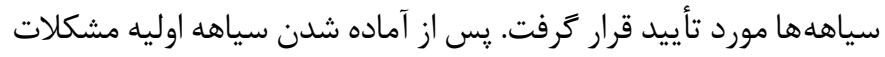

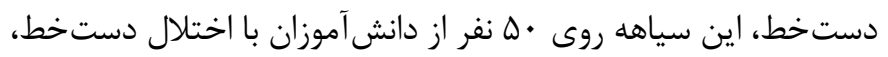

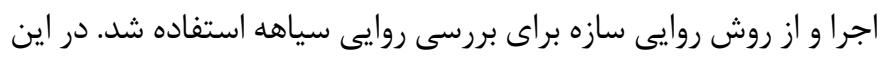

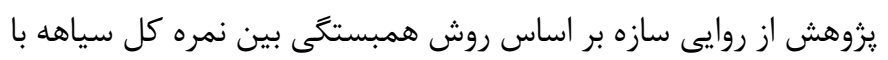

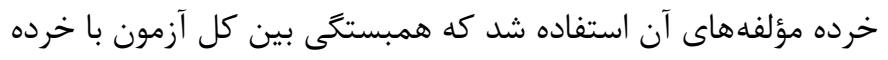

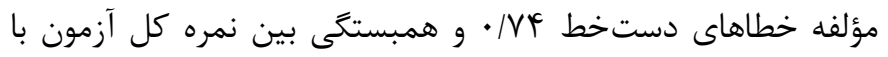
خرده مؤلفه خطاهاى وضعيت بدن موقع نوشتن • // • به دست آمد. براى تعيين يايايى سياهه از ضريب آلفاى كرونباخ استفاده شد كه ميزان ضريب آلفاى كل \&\&/ • بدست آمد كه ضريب خوبى است (rآ).

آزمون ماتريس هاى بيشرونده ريون (Raven): اين آزمون متشكل

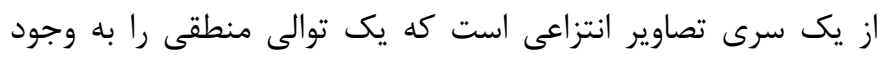

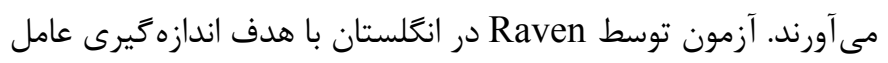

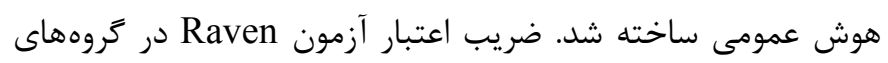

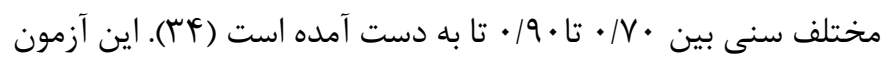

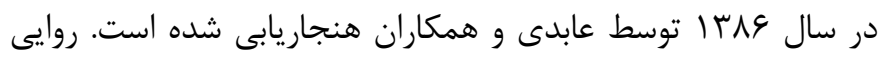

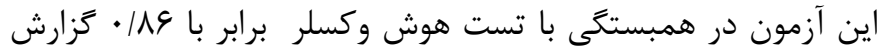

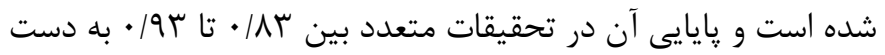

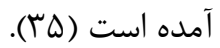

مقياس استدلال ادراكى وكسلر جهار (WAIS-IV): اين مقياس

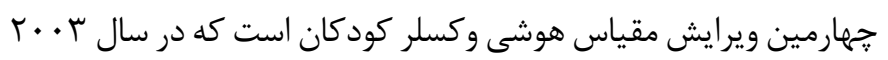

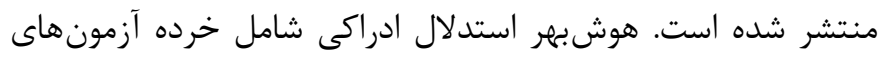

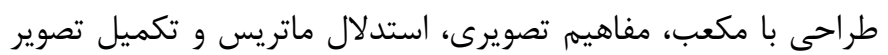
است. اين آزمون در سال عیبا توسط صادقى و همكاران ضرايب

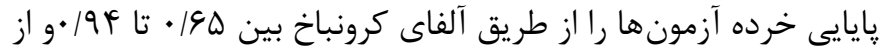
طريق روش تنصيف بين 9// • تا /9/ • كزارش شده كردهاند، همجنين ضرايب يايايى هوشبهر استدلال ادراكى بيش از / / مى باشد كه نشان
دستخط در يزوهش كشاورزى و همكاران (זr)، از نظر مشكلات

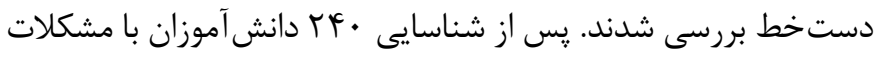

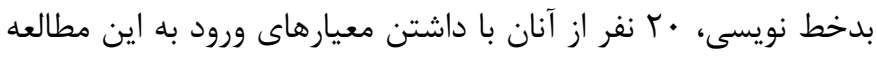
انتخاب و سيس به روش گمارش تصادفى در دو كروه كنترل (· • ( نفر ) و

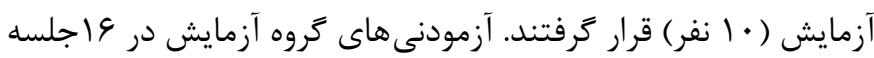

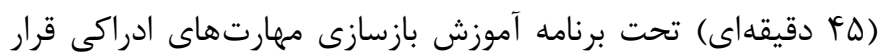

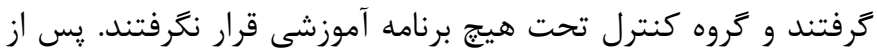
يايان اجراى برنامه مداخله، براى هر دو گروه آزمايش و كنترل، سياهه

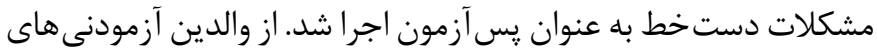
كروه آزمايش فرم رضايت و تعهد جهت شركت فرزندانشان دركلاس

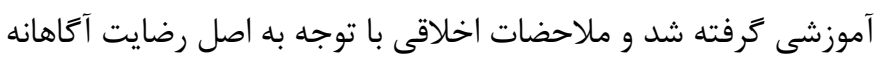

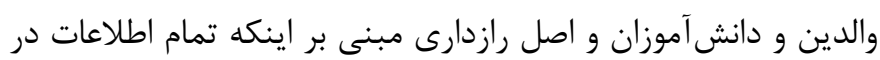

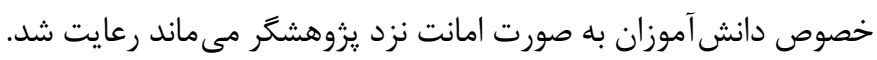

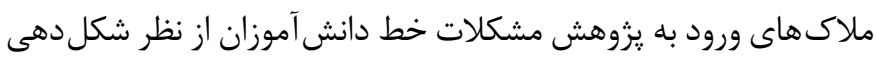
ضعيف حروف، نوشتن حروف به صورت خيلى بزرى يا خيلى كوجى

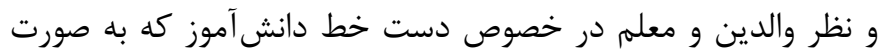
شكايت در كند نويسى يا فاصله گذارى زياد بين حروف بود كه تنها ناتوانى كودى در زمينه نوشتن و دستخط و نداشتن اختلالات ديخر در زمينه خواندن يا رياضيات بود. ملاكهاى خروج از يزوهش داشتن

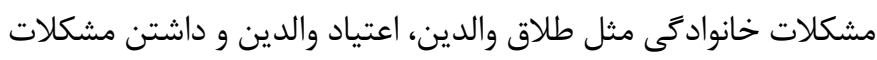
اقتصادى_اجتماعى، داشتن مشكلات حسى_حر كتى و مشكلات بينايى منيى

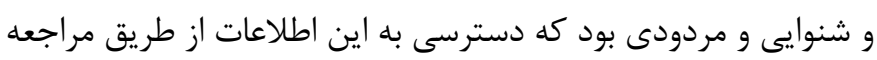

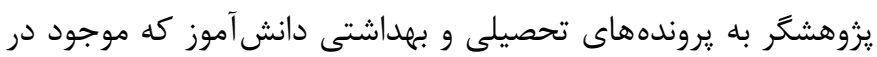

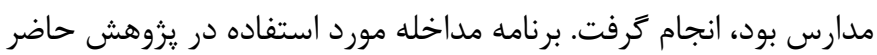

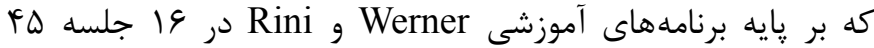

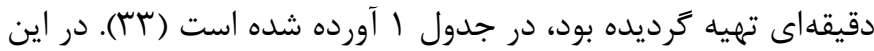

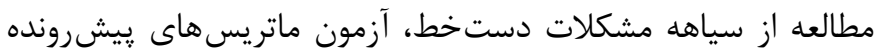
ريون (Raven)، مقياس استدلال ادراكى وكسلر جهار (WAIS-IV)

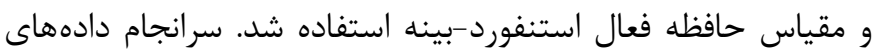

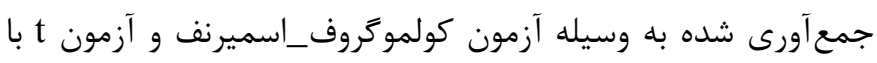
برنامه SPSS-20 مورد تحليل قرار ترفت.

سياهه محقق ساخته مشكلات دستخط: براى سنجش مشكلات دستخط دانشآموزان از سياهه مشكلات دستخط استفاده شد. براى ساخت اين سياهه از منابع گوناگون از قبيل كتابها، نشريات، كزارش يزوهش ها و منابع الكترونيكى و مصاحبه با معلمان استفاده شد. سياهه محقق ساخته مشكلات دستخط شامل 9ب گَويه و دو خرده 
توسط افروز و كامكارى در تهران با حجم . .11 نفر و سيس در كل

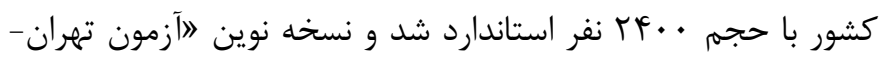
استنفورد-بينه/ ناميده شد. آزمون بينه در r حيطه كلامى و غير كلامى و ه عامل مطرح شده كه شامل استدلال سيال، دانش، استدلال كمى، يردازش ديدارى_فضايى و حافظه فعال است كه هر دو حيطه را شامل مى شوند. در مقياس استنفورد-بينه، با تاكيد به تجانس درونى در زمينه

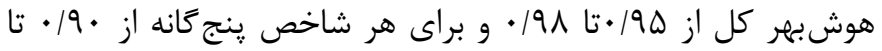

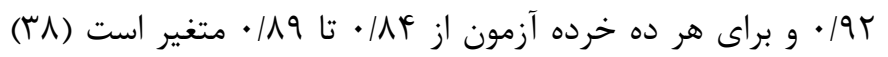

پايا بودن آزمون است. روايى آزمون نيز در سطح مطلوبى گزارش شده است (عץ). نمره استدلال ادراكى شامل خرده آزمونهاى طراحى با رونى مكعب، مفاهيم تصوير، استدلال ماتريس و تكميل تصوير بود كه نمرات خام با توجه به سن دانشآموزان به نمره تراز تبديل شد كه تاثير دو متغير مستقل بر آن مورد بررسى قرار گرفت.

مقياس حافظه فعال استنفورد_بينه: اين مقياس در سال ץ+.

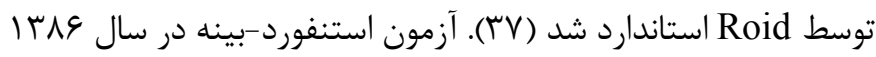

جدول ا. اهداف و محتواى جلسات آموزشى

\begin{tabular}{|c|c|c|}
\hline محتوا & هدف & جلسات \\
\hline 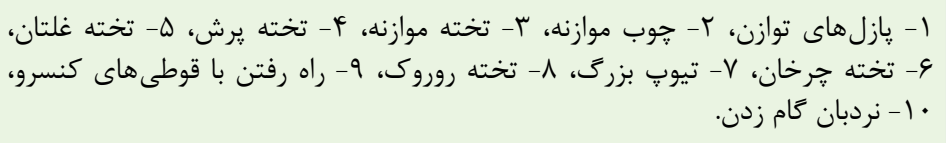 & آموزش توازن و تمرينات مرتبط با آن & اول \\
\hline 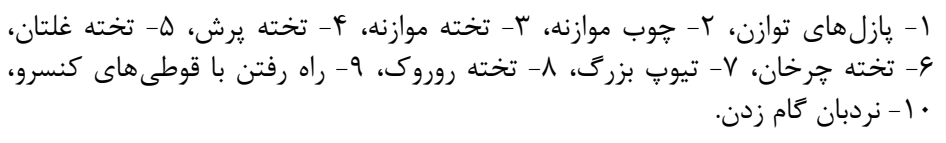 & تمرينات ديخرى مرتبط با آموزش توازن & دوم \\
\hline 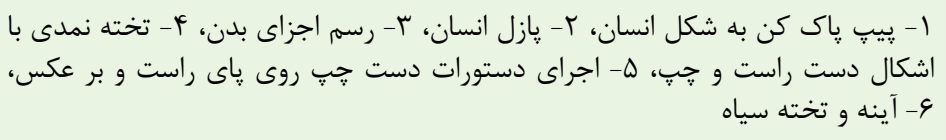 & آموزش تن آكاهى، نقش اندامها و تمرينات مرتبط با آن & سوم و جههارم \\
\hline 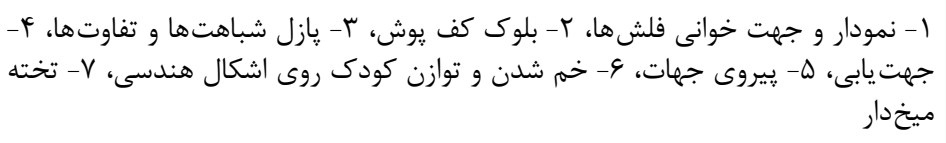 & آموزش آكاهى فضايى (مكان) و تمرينات مرتبط با آن & ينجم و ششم \\
\hline 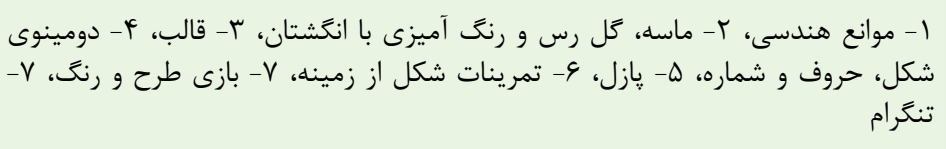 & آموزش ادراى شكل و تمرينات مرتبط با آن & هفتم و \\
\hline 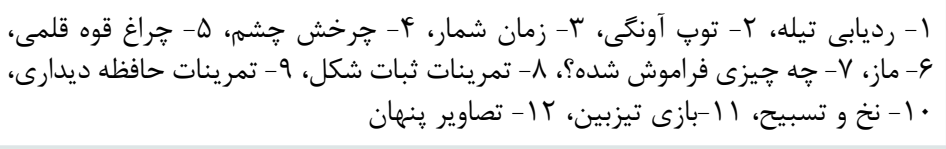 & آموزش ادراك بينايى و تمرينات مرتبط با آن & نهم و دهم \\
\hline 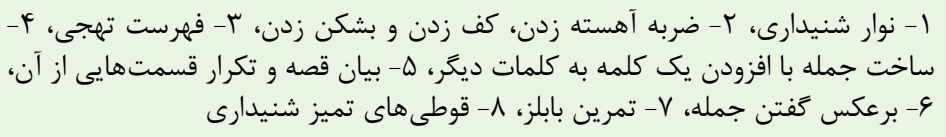 & آموزش ادراك شنيدارى و تمرينات مرتبط با آن & دوازدهم و \\
\hline
\end{tabular}

وافوته

تحليل جند متغيرى و شاخص لامبداى ويلكز مورد بررسى قرار گرفت. همان طور كه در جدول r مشاهده مى گردد، اثر زمان و اثر تعاملى زمان در گروه از نظر آمارى معنادار بود. با توجه به اين كه اثر تعاملى از نظر آمارى معنادار بود، در ادامه از آزمون
نتايج آزمون كولموگروف_اسميرنف نشان داد كه دادهاى يزوهش حاضر داراى توزيع نرمال بوده است (ه> (P>). بنابراين از آزمون يارامتريك تحليل واريانس مختلط (Y×Y) براى تجزيه و تحليل دادهها استفاده شد. لازم به ذكر است كه در يزوهش حاضر نتايج بر اساس 
نتايج جدول r نشان مى دهد كه تفاوت معنادارى در دستخط، حافظه تعقيبى tوابسته براى بررسى اثر درون گروهى به تفكيك گروهها و آزمون فعال كلامى، حافظه فعال غير كلامى و استدلال ادراكى بين ييش آزمون

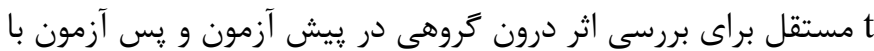
تا يس آزمون فقط در گروه بازسازى مهارتهاى ادراكى وجود داشت.

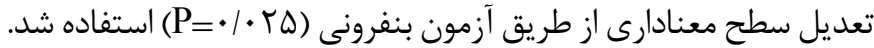

جدول r. نتايج شاخص لامبداى ويلكز از تحليل واريانس مختلط

\begin{tabular}{|c|c|c|c|c|c|}
\hline اندازه اثر & $\mathbf{P}$ & $\mathbf{F}$ & ارزش - ارز & 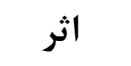 & متغير \\
\hline .1949 & $\cdot 1 \cdots \cdot 1$ & $F F / \cdot V$ & $\cdot / r v \mid$ & زمان & \multirow{2}{*}{ دست خط } \\
\hline $.19 \vee \Delta$ & $\cdot \mid \cdots)$ & $\Delta \Gamma / Q \Delta$ & . TrS & زمان×كروه & \\
\hline - /TEY & $\cdot 1 \cdot \omega$ & Q/Tr & . & زمان & \multirow{2}{*}{ حافظه فعال كلامى } \\
\hline$\cdot / r \cdot r$ & .1 .19 & $4|9|$ & $\cdot / \vee 9 \vee$ & زمان×كروه & \\
\hline$\cdot|\Delta T|$ & $\cdot \mid \cdots \cdot$ & TN/TF & $\cdot / 4 \vee q$ & زمان & \multirow{2}{*}{ حافظه فعال غير كلامى } \\
\hline$\cdot / F \vee \wedge$ & $\cdot \mid \cdots 1$ & TH/AT & - IDTY & زمان×كَروه & \\
\hline.$|9| r$ & $\cdot \mid \cdots \cdot$ & fI/9r & • & زمان & \multirow{2}{*}{ استدلال ادراكى } \\
\hline$\cdot \mid 901$ & $\cdot 1 \cdot \cdots 1$ & FN/FT & . / r $4 q$ & زمان×كروه & \\
\hline
\end{tabular}

جدول r. نتايج آزمون t وابسته

\begin{tabular}{|c|c|c|c|c|c|c|}
\hline $\mathbf{P}$ & $\mathbf{t}$ & درآزادى & يس آزمون & 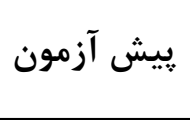 & تروه & متغير \\
\hline$\cdot 1 \cdot \cdot 1$ & $-\Lambda / \uparrow \varphi$ & r & $M Y / T I$ & rV/IF & بازسازى مهارت هاى ادراكى & \multirow{2}{*}{ دست خط } \\
\hline - IDFT & .1948 & r & $r F / V q$ & $r \Delta / I F$ & 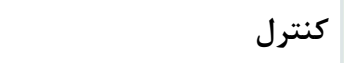 & \\
\hline$\cdot 1 \cdot 1$ & $-F / F F$ & r & $19 / 79$ & $19 / V 9$ & بازسازى مهارتهاى ادراكى & \multirow{2}{*}{ حافظه فعال كلامى } \\
\hline$\cdot|v 9|$ & $-\cdot|r|$ & ir & $|N /| F$ & IV/qu & 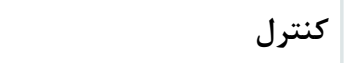 & \\
\hline $.1 \cdot 1$ & $-G / V Y$ & r & $r 1 / r q$ & $1 V / 94$ & بازسازى مهارتهاى ادراكى & \multirow{2}{*}{ حافظه فعال غير كلامى } \\
\hline - NYES & 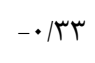 & r & $\mid V / G 4$ & $I V / \Delta$ & كنترل & \\
\hline$\cdot 1 \cdot \cdot 1$ & $-V / I V$ & ז & $\Lambda r / \Delta \cdot$ & GT/GY & بازسازى مهارتهاى ادراكى & \multirow{2}{*}{ استدلال ادراكى } \\
\hline$\cdot 10 \cdot t$ & $-r / \uparrow \varphi$ & r & $\Delta r / \Delta V$ & $\Delta F / T q$ & كنترل & \\
\hline
\end{tabular}

در متغيرهاى دست خط، حافظه فعال غير كلامى و استدلال ادراكى در مرحله يس آزمون بين كروه آزمايش و كنترل تفاوت معنادارى وجود

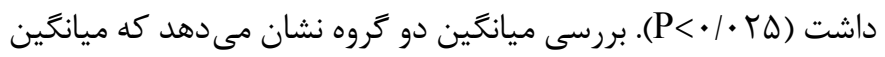
گروه آزمايش (تمرينات بازسازى مهارت هاى ادراكى) نسبت به گروه كنترل بيشتر است.
همانطور كه در جدول f مشاهده مىشود، تفاوت معنادارى بين دو كروه آزمايشى و كنترل در مرحله ييش آزمون در متغيرهاى دست خط، حافظه فعال كلامى، حافظه فعال غير كلامى و استدلال ادراكى وجود

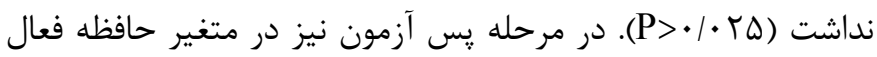
كلامى تفاوتى معنادارى بين گروه آزمايش و كنترل وجود نداشت؛ اما 
جدول ع. نتايج آزمون t مستقل

\begin{tabular}{|c|c|c|c|c|}
\hline $\mathbf{P}$ & $\mathbf{t}$ & درجه آزادى & مر حله & متغير \\
\hline$\cdot / r v$ & $\cdot / 9 \cdot r$ & rq & ي بيش آزمون & \multirow{2}{*}{ دست خط } \\
\hline$\cdot \cdots \cdot 1$ & $\Delta / 9 \varphi$ & rq & يس آزمون & \\
\hline$\cdot / r$ & $-1 / r$ & rq & ي بيش آزمون & \multirow{2}{*}{ حافظه فعال كلامى } \\
\hline$\cdot / \cdot v$ & $1 / 19$ & re & يس آزمون & \\
\hline .109 & $\cdot / \Delta r$ & rq & بيش آزمون & \multirow{2}{*}{ حافظه فعال غير كلامى } \\
\hline$\cdot 1 . .1$ & r/Ar & rq & يس آزمون & \\
\hline .119 & I/rr & rq & يِيش آزمون & \multirow{2}{*}{ استدلال ادراكى } \\
\hline 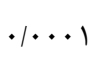 & $\Delta / \& \Delta$ & rq & يس آزمون & \\
\hline
\end{tabular}

و دستخط را مورد ارزيابى قرار دادند. نتايج نشان داد كه تنها امور

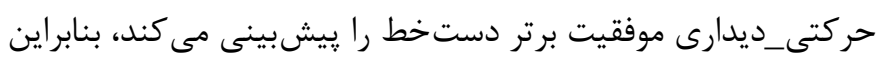

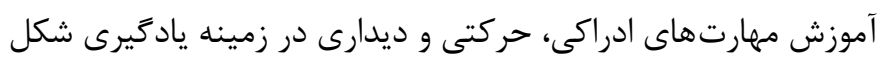

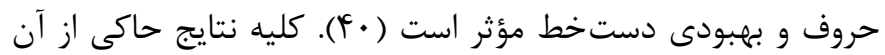
بود كه بين تقويت هماهنكى خشم و دستنويسى ارتباط قوى وجود دارد. هر يك از تمرينات معمول جهت آموزش دستنويسى باعث تقويت هماهنكى اندام هاى فوقانى، حافظه بينايى، روابط فضايى، ثبات

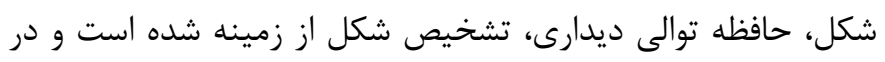
افزايش سرعت و ظرافت حركات در اندامهاى فوقانى نقش مهمى ايفا

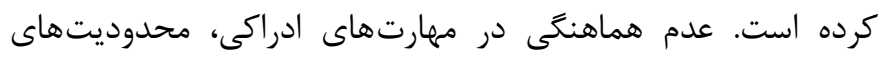

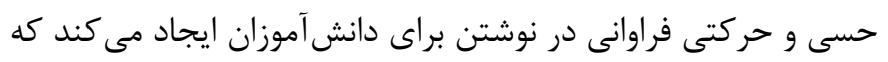

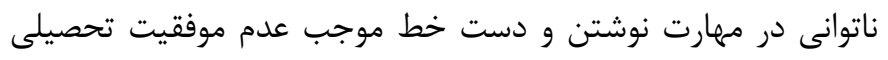

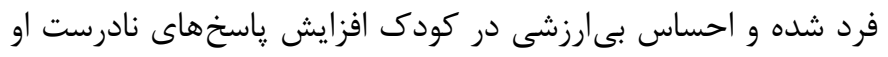
به خواستهاى آموزشى مى كردد. بنابراين غنى بودن تجارب ادراكى كودى در زمينههاى مختلف ادراكى و حركتى و افزايش توانايى وى در درى تقويت مهارتهاى دستنويسى در فرايند يِيشيرى اصلاح و

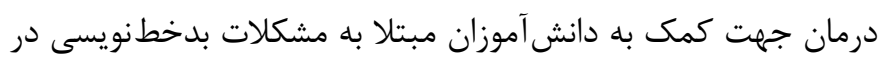

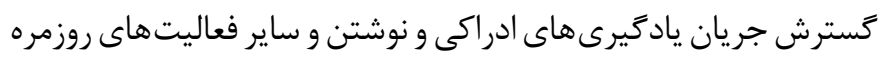

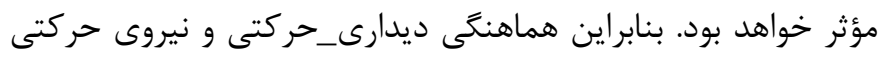

هدف يروهش حاضر مطالعه اثربخشى آموزش مهارتهاى ادراكى بر

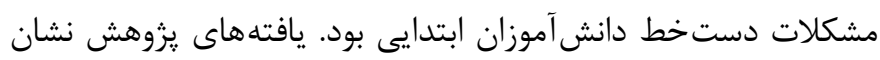

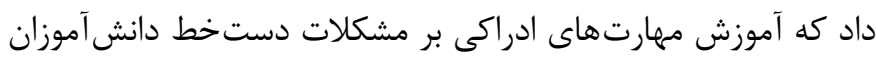

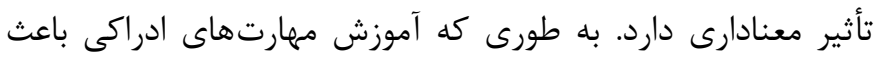
كاهش مشكلات دست خط دانش آموزان شده است. بنابراين تمرينهاى شناختى_حركتى از جمله تقويت هماهنكى خشم و دست، توالى ديدارى، توجه و تمركز و تقويت حركات ظريف انگشتان دست برتر بر

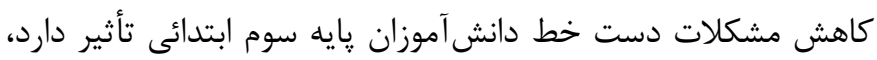

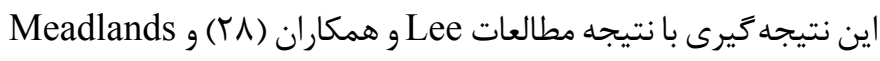

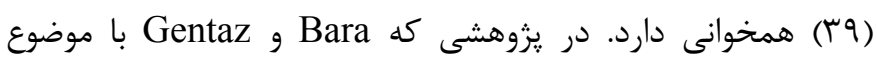

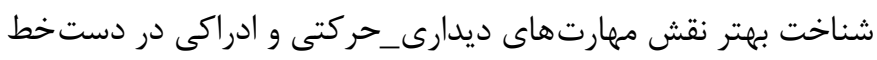

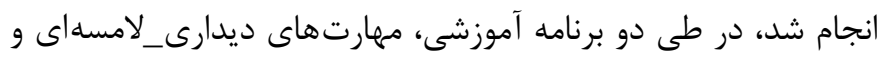

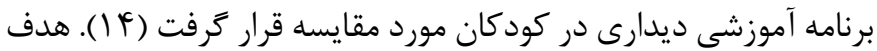
از اين تحقيق كه بر روى درستنويسى حروف (كيفيت دستخط) بود.

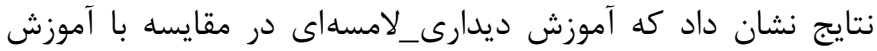
ديدارى باعث عملكرد بهترى در شناخت حروف و كيفيت دست خط شد. زيرا باعث بهبود مهارتهاى ادراكى_حركتى ديدارى مى شود.

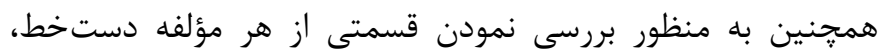

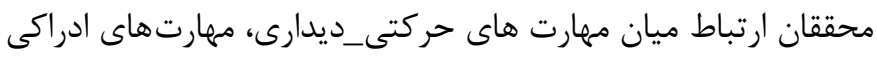


ماهيت فعاليتهاى حركتى داشت (هأ). براى شناخت بهتر نقش مهارتهاى ادراكى و بصرى در نوشتن دو مطالعه انجام شد كه در آن نقش مهارتهاى ادراكى و بصرى مقايسه شدهاند. نتايج دو تمرين كه در دانشآموزان مورد بررسى قرار گرفته بود متفاوت بود. نتايج نشان داد كه بهبود مهارتهاى ادراكى و بصرى بر روى كيفيت

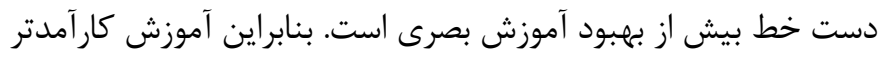

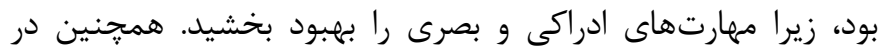

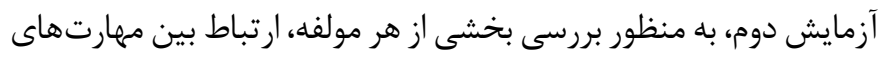

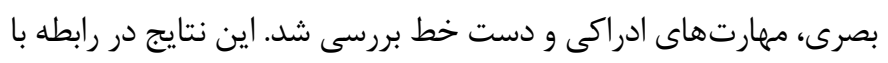
نقش هاى متفاوتى از مهارتهاى ادراكى و بصرى در شكل دادن به شكل

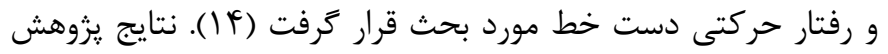
سلمان و همكاران نشان داد كه تمرينهاى ادراكى و حركتى سبب بهبود

اختلال هماهنكى رشدى كودكان مىشود (\&\$).

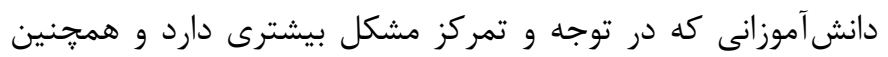

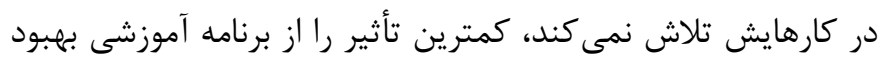

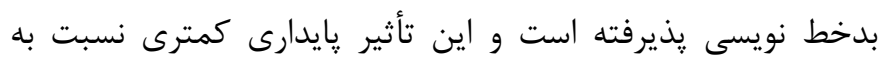

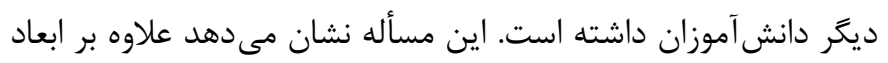

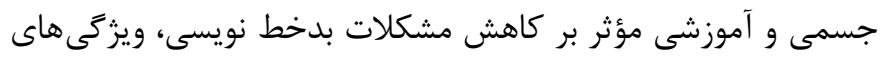
شخصيتى و همجنين بُعد هيجانى و روانى افراد در بهبود دست خطشان تأثير دارد. در رابطه با اين موضوع تحقيقات نشان داده است دانش دانش آموزان با اختلال يادكيرى كه دستخط نيز يكى از زيرمجموعههاى آن است ممكن است با مشكلاتى در عواطف مثبت و منفى و هيجان مواجه

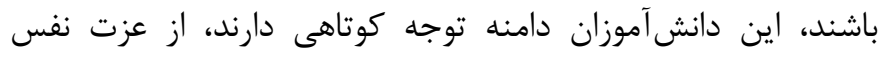

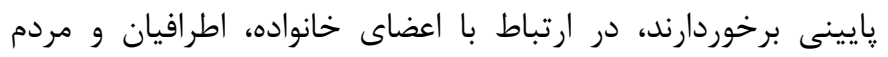

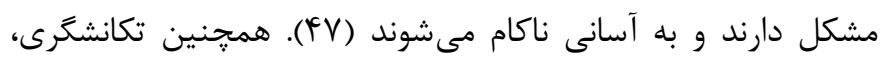

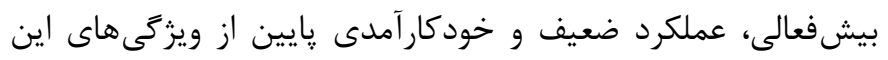

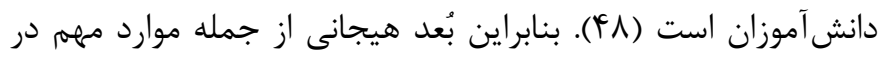

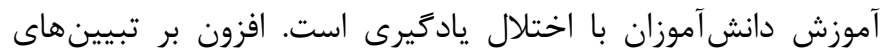

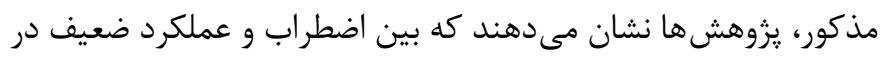
دانش آموزان با ناتوانى يادكيرى رابطه قوى وجود دارد. يعنى اضطراب دانش آموزان با ناتوانى يادكيرى باعث مى شود كه عملكردشان ضعيفتر

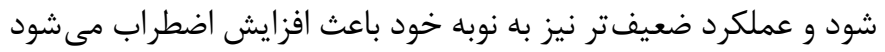

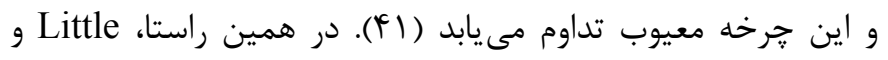

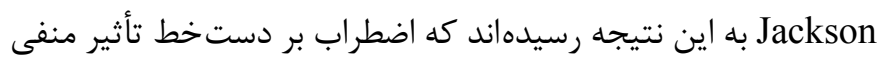

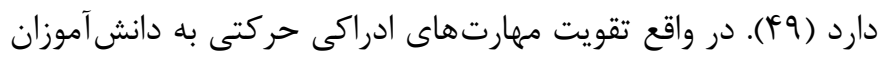

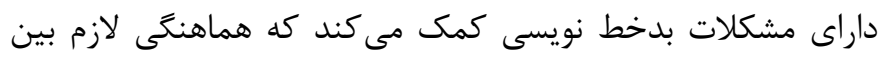
حر كات عضلات، كنترل شده و ملايم در نوشتن و تمام كارهاى كودكان
دست از عوامل بيشبينى كننده خوانايى دستخط در دانشآموزان ابتدائى است كه دانشآموزان ياد مى گيرند رفتار و يادگيرى خودشان بان را بهتر مديريت كنند كه همين امر موجب بهبود وضعيت نشستن در

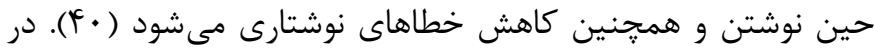

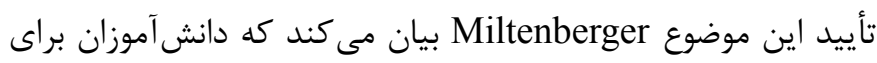

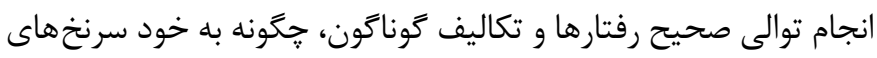

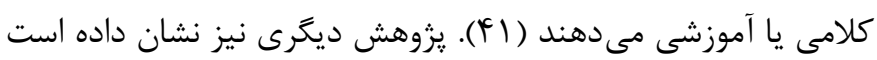

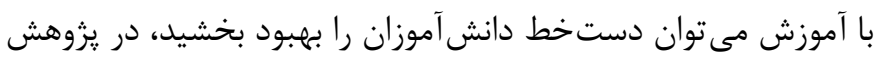

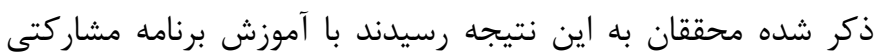

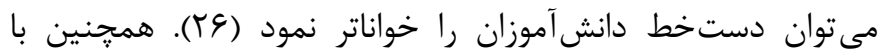
آموزش مهارتهاى خودآموزى به دانشآموزان داراى مشكلات بدخط

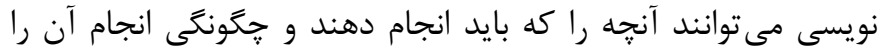
در موقعيتهاى گوناگون به خود بكَويند و بلافاصله پِ از وقوع رفتار مناسب، جملات خود تحسينى بكويند و ارزيابى مثبتى از رفتار خود داشته باشند تا از اين طريق عملكرد خود را بهبود بخشند ( أl). علاوه

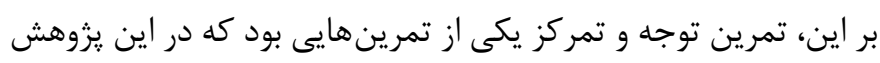

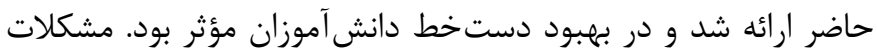
توجه و تمركز يكى از مسائل عمدهاى است كه كودكان مبتلا به اختلال يادگيرى با آن مواجه هستند، اين مشكلات در واقع مربوط به فقدان توجه انتخابى در دانش آموزان مىشود كه باعث مىشود دانش آموز به هنكام يادكيرى به مطلب اصلى توجه نداشته باشد (TF). مشكلات

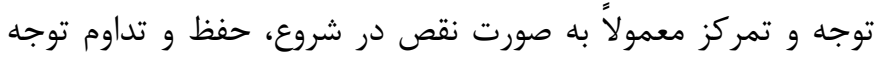

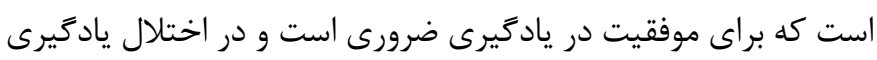

بايد مورد توجه قرار گيرد (سأ). انقباض در ديستونى دست مشكل خاصى است. اين ناهماهنغى از إز

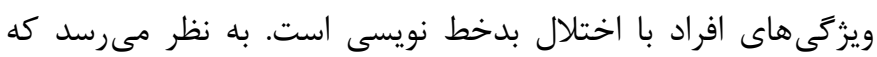

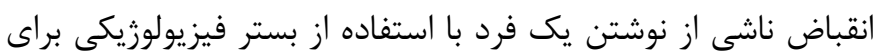
توليد اختلال، زمان زيادى را صرف نوشتن مى كند. پس زمينه بارور كه به احتمال زياد زنتيكى است ممكن است كاهش مهار، افزايش يلاستيسيته يا اختلال در عملكرد حسى باشد. يافته هاى ياتوفيز يولوزى

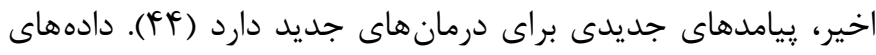

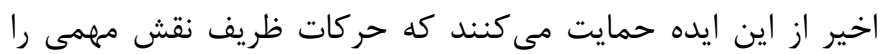

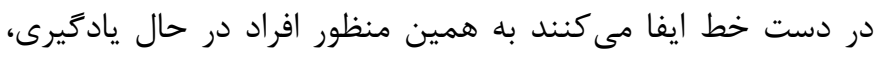

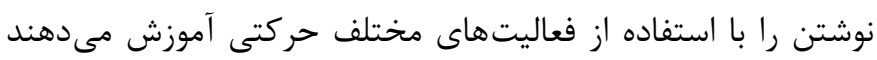

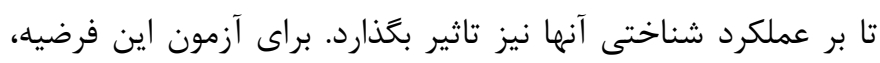

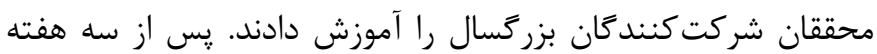
تمرين، يك سرى آزمايش انجام گرفت كه نياز به بردازش تصويرى و 
مشكلات بدخط نويسى دارد، اين روش مىتواند به عنوان بخشى از

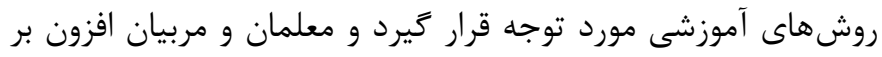

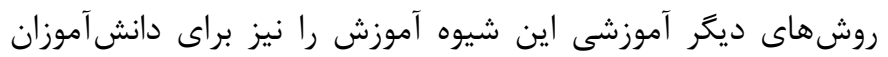
داراى مشكلات دست خط اجرا كنند.

\section{نتيجه كيرى}

بر اساس يافته هاى يزوهش حاضر، علاوه بر ابعاد جسمى و آموزشى مؤثر بر كاهش مشكلات خط، بايد به عوامل ديكرى از جمله ويزگى هاى شخصيتى دانشآموز نيز توجه نمود. طبق مشاهداتى كه در هنگام

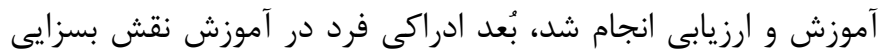
دارد، بنابراين مى توان برنامه بازسازى مهارتهاى ادراكى را براى بهبود بهائ بدخط نويسى در دانش آموزان ابتدائى به كار برد.

\section{تشكر و قدرهانى}

در پايان از تمامى افرادى كه در اين يزوهش ما را يارى كردند به خصوص مديران مدارس ابتدايى استان خراسان رضوى و تمامى والدين و دانش آموزان شركت كننده در اين يزوهش تشكر و قدردانى مى گردد.

\section{References}

1. Akhavan Tafti M, Heidarzadeh M, Khademi M. A comparison of multiple intelligences profile of students with and without learning disabilities. International Journal of Applied Psychology. 2014;4(3):121-125. (Persian)

2. Ganji M. Psychology of exceptional children based on DSM-

5. 1st ed. Tehran:Savalan Publications;2013. (Persian)

3. National Joint Committee on Learning Disabilities. Learning disabilities and young children: Identification and intervention. A report from the National Joint Committee on Learning Disabilitie. Learning Disability Quarterly. 2007;30(1):63-72.

4. American Psychiatric Association. Diagnostic and statistical manual of mental disorders (DSM-5®). Arlington VA: American Psychiatric Association;2013.

5. Krapic N, Hudek-Knezvic J, Kardum I. Stress in adolescence: Effects on development. In: Smelser NJ, Baltes PB, editors. International Encyclopedia of the social and behavioral
اثر داشته و از اين طريق عملكرد خود را بهبود بخشند كه بهبود عملكرد نيز به نوبه خود باعث كاهش اضطراب مىشود و اين جرخه در مسير صحيح قرار مى گيرد. همجنين تحول مهارتهاى ادراكى دانشآموزان داراى مشكلات دست خط باعث مىشود كه آنها، ييشرفت و موفقيتى كه در اثر آموزش اين مهارت ها كسب كردهاند را به خود نسبت دهند و آن را ناشى از تلاشهاى حركتى و ادراكى خود بدانند. از اين رو آموره مى توان استدلال كرد كه آموزش و تحول مهارت هاى ادراكى و حركتى باعث تغيير سبك اسادى منفى دانشآموزان بدخط نويس مىشود و در نتيجه دست خط آنها بهبود مى يابد. بايد يادآورى شود كه با توجه به محدود بودن حجم نمونه، در تعميم نتايج به دست آمده از نمونه به جامعه بايستى احتياط كرد. همجنين يزوهش حاضر فقط بر روى دانش آموزان يسر داراى مشكلات بدخط نويسى انجام شد، بنابراين در تعميم نتايج آن به دانش آموزان دختر داراى مشكلات دست خط دقت شود. يِيشنهاد مى شود تأثير آموزش مهارتهاى ادراكى بر مشكلات دستخط دانش آموزان دختر مورد يزوهش قرار گيرد. يِيشنهاد مى شود از آزمونهاى پيخير جهت تعميهيذيرى بهتر نتايج استفاده شود. با توجه به تأثير بسزايى كه شيوه آموزش ادراكى بر دانشآموزان داراى

sciences. 2nd ed. Philadelphia, PA:Elsevier;2015. pp. 562-569. 6. Khodam H, Modanlou M, Ziaei T, Keshtkar AA. Behavioral disorders and related factors in school age children of Gorgan. Iranian Journal of Nursing Research. 2009;4(14):29-37. (Persian)

7. Freilich R, Shechtman Z. The contribution of art therapy to the social, emotional, and academic adjustment of children with learning disabilities. The Arts in Psychotherapy. 2010;37(2):97105.

8. Auerbach JG, Gross-Tsur V, Manor O, Shalev RS. Emotional and behavioral characteristics over a six-year period in youths with persistent and nonpersistent dyscalculia. Journal of Learning Disabilities. 2008;41(3):263-273.

9. Badeleh A, Toomaj A. Structural equations of relationships between learning disorder, emotional intelligence and depression in primary school students. Quarterly Journal of Child 
Mental Health. 2018;4(4):59-70. (Persian)

10. Kamran A, Moghtadaie K, Abdali Z, Salamat M. The effectiveness of attention training on improving the academic performance of students with spelling learning disabilities. Quarterly Journal of Child Mental Health. 2017;4(1):46-55. (Persian)

11. Ganji M, Zahed-Babelan A, Moeini Kia M. Meta-analysis of studies carried out regarding the role of teaching models in students' academic achievement. Journal of School Psychology. 2012;1(1):93-107.

12. Fahangi A, Abdolalian M. The Effectiveness of social skills training on self-concept and anxiety sensitivity students with learning disabilities. Journal of Learning Disabilities. 2016;5(4):43-58. (Persian)

13. Lam SS, Au RK, Leung HW, Li-Tsang CW. Chinese handwriting performance of primary school children with dyslexia. Research in Developmental Disabilities. 2011;32(5):1745-1756. 14. Bara F, Gentaz E. Haptics in teaching handwriting: The role of perceptual and visuo-motor skills. Human Movement Science. 2011;30(4):745-759.

15. Salimi M. Impairment in writing. Exclusive Education Magazine. 2008;6(8):22-33. (Persian)

16. Amundson SJ. Evaluation tool of children's handwriting: ETCH examiner's manual. Homer, AK:OT KIDS, Inc;1995.

17. Khosro Javid M, Ghavami Iahij S. A study of the factors influencing primary students' handwriting legibility from the teacher's viewpoint. Journal of Learning Disabilities. 2012;1(3):29-45. (Persian)

18. Feder KP, Majnemer A. Handwriting development, competency, and intervention. Developmental Medicine \& Child Neurology. 2007;49(4):312-317.

19. Poon KW, Li-Tsang CW, Weiss TP, Rosenblum S. The effect of a computerized visual perception and visual-motor integration training program on improving Chinese handwriting of children with handwriting difficulties. Research in Developmental Disabilities. 2010;31(6):1552-1560.

20. Marr D, Dimeo SB. Outcomes associated with a summer handwriting course for elementary students. American Journal of Occupational Therapy. 2006;60(1):10-15.

21. Vinter A, Chartrel E. Visual and proprioceptive recognition of cursive letters in young children. Acta Psychologica. 2008;129(1):147-156.

22. Engel-Yeger B, Nagauker-Yanuv L, Rosenblum S. Handwriting performance, self-reports, and perceived self-efficacy among children with dysgraphia. American Journal of Occupational Therapy. 2009;63(2):182-192.

23. Tseng MH, Fu CP, Cermak SA, Lu L, Shieh JY. Emotional and behavioral problems in preschool children with autism: Relationship with sensory processing dysfunction. Research in Autism Spectrum Disorders. 2011;5(4):1441-1450.

24. Heidari M, Sadaghiani T. The relationship between different pencil grip patterns and legibility of handwriting in normal firstgrade students. Journal of Modern Rehabilitation. 2010;3(3):1015. (Persian)

25. Kushki, F, Ilyas F, Chau T. Changes in Kinesthetic and Kind Mastic of Handwriting during a prolonged writing task in children with and without dysgraphia. Research in Developmental Disabilities. 2011;32(3):1058-1064.

26. Case-Smith J, Holland T, Lane A, White S. Effect of a co-teaching handwriting program for first graders: One-group pretest-posttest design. American Journal of Occupational Therapy. 2012;66(4):396-405.

27. Schwellnus H, Carnahan H, Kushki A, Polatajko H, Missiuna C, Chau T. Effect of pencil grasp on the speed and legibility of handwriting in children. American Journal of Occupational Therapy. 2012;66(6):718-726.

28. Lee T, Howe TH, Chen H. L Wang TN. Predicting handwriting legibility in Taiwanese elementary school children. American Journal of Occupational Therapy. 2016;70(6)1-9. 29. Azad A, Havayee N, Rafie SH, Keyhani MR. Comparison of hand sensory-motor skills between normal and dysgraphia children in 9-11 ages. Journal of Modern Rehabilitation. 2008;1(4):5-12. (Persian)

30. Keshavarzi F, Shojaii S. The effectiveness of self-learning skills training on the associate's problems of the school of 
male-specific disability with the type of Nazism. Quarterly Exceptional Persons. 2014;5(19):210-231. (Persian)

31. Ghobari Bonab B, Nosrati F, Sharifi S. Application of self-instruction in modifying the handwriting of students with specific learning disorder. Journal of Learning Disabilities. 2016;6(1):100-120. (Persian)

32. Keshavarzi F, Shojaee S. The effectiveness of self-instruction skills training on handwriting problems of boy students having specific learning disability with dysgraphia type. Psychology of Exceptional Individuals. 2015;5(19):150-165. (Persian)

33. Werner R, Rini L. Perceptual-motor development equipment: Inexpensive ideas and activities. (Sazmand A, Tabatabaii M, translators). $3^{\text {th }}$ ed. Tehran:Danhze Publication;2014. (Persian)

34. Tamez E, Myerson J, Hale S. Learning, working memory and intelligence revisited. Journal of Behavioral Processes. 2008;78(2):240-245.

35. Abedi A, Piroo Zijerdi M, Yarmohammadian A. The effectiveness of training attention on mathematical performance of students with mathematics learning disability. Journal of Learning Disabilities. 2012;2(1):92-106. (Persian)

36. Sadeghi A, Rabiee M, Abedi MR. Validation and reliability of the Wechsler Intelligence Scale for Children-IV. Developmental Psychology: Journal of Iranian Psychologists. 2011;7(28):377386. (Persian)

37. Roid GH, Carlson AD. Special composite scores of the SB5. (Stanford-Binet Intelligence Scales, Fifth Ed Assessment Service Bulletin No. 4). Itasca IL:Riverside Publishing;2003.

38. Kamkary K, Afruz Gh. Standardization of intelligence testing in Tehran-Stanford-Binan Minor [PhD Dissertation]. Tehran:Tehran University;2007(Persian)

39. Meadlands AF. Handwriting and perceptual- motor skills in clumsy, and normal children. Perceptual and Motor Skills. 1992;75(Supl 3):1207-1217.

40. Sohrabi N, Samani S, Sheybani T. The Effect of perceptu- al-motor skill training on hand writing and draw with developmental coordination disorder [MA Thesis]. Marvdasht:Islamic Azad University, Marvdasht Branch;2012. (Persian)

41. Miltenberger RG. Behavior modification: Principles and procedures. $5^{\text {th }}$ ed. Pacific Grove, CA:Wadsworth Cengage Learning;2011.

42. Sabornie EJ. Social-affective characteristics in early adolescents identified as learning disabled and nondisabled. Learning Disability Quarterly. 1994;17(4):268-79

43. Bauminger N, Schorr Edelsztein H, Morash J. Social information processing and emotional understanding in children with LD. Journal of Learning Disabilities. 2005;38(1):45-61.

44. Hallett M. Pathophysiology of writer's cramp. Human Movement Science. 2008;25(4-5):454-463.

45. Longcamp M, Boucard C, Gilhodes JC, Velay JL. Remembering the orientation of newly learned characters depends on the associated writing knowledge: A comparison between handwriting and typing. Human Movement Science. 2006;25(45):646-656.

46. Salman Z, Sheikh M, Seyf Naraghi M, Arab Ameri E, Aghapour M. The effects of perceptual motor training on improving motor abilities of elementary children with developmental coordination disorder in Tehran. Motor Learning and Movement "Harakat". 2009;1(2):47-63. (Persian)

47. Sausser S, Waller RJ. A model for music therapy with students with emotional and behavioral disorders. The Arts in Psychotherapy. 2006;33(1):1-10.

48. Hulbert-Williams L, Hastings RP. Life events as a risk factor for psychological problems in individuals with intellectual disabilities: A critical review. Journal of Intellectual Disability Research. 2008;52(11):883-895.

49. Little S, Jackson B. The treatment of test anxiety through attentional and relaxation training. Psychotherapy: Theory, Research \& Practice. 1974;11(2):175-178. 